\section{Individual Shoot Defoliation Minimally Affects Pecan Return Bloom}

\author{
Michael W. Smith ${ }^{1,3}$ and Becky S. Cheary ${ }^{2}$ \\ Department of Horticulture and Landscape Architecture, 360 Agricultural \\ Hall, Oklahoma State University, Stillwater, OK 74078
}

Additional index words. alternate bearing, Carya illinoinensis, crop load, flower, flowering, fruit thinning, irregular bearing

\begin{abstract}
Alternate bearing of pecan [Carya illinoinensis (Wangenh.) K. Koch] remains the leading problem of the industry. Several cultural practices have been developed or improved to mitigate alternate bearing. Premature defoliation was one problem identified that substantially decreased return bloom. The objective of this study was to determine the response of individual shoots exposed to various defoliation treatments. In one study, individual vegetative or bearing shoots were hand-defoliated in midSeptember. Defoliation was the basal one-half, distal one-half, entire shoot, or not defoliated. Another study applied the same defoliation treatments to bearing shoots in July, August, or September. Defoliation had minimal effects on return bloom and rarely affected the percentage of current-season shoots fruiting the next year. Defoliation date also had little effect on return bloom. These data indicate that individual shoot response to defoliation was not autonomous and has implications for determining crop overload and needed mechanical fruit thinning.
\end{abstract}

Pecan alternate bearing remains a major industry problem (Smith and Weckler, 2011), although basic information regarding flowering regulation has expanded (Bangerth, 2009; Wood, 2011). Current theory of angiosperm fruit tree flowering regulation supports a levelone autonomous floral pathway with signaling by a mobile flowering locus $\mathrm{T}$ protein (Yang et al., 2007) and a level-two long-distance floral signal that engages histones affecting chromatin configuration and thus accessibility to particular genes for transcription (Kouzarides, 2007; Nelissen et al., 2007).

Premature defoliation, i.e., before a normal killing frost, of the entire tree markedly reduces pistillate flowers the next year (Hinrichs, 1962; Worley, 1979a). Early defoliation may negatively impact pistillate flower production by reducing available non-structural carbohydrates (Worley, 1979b) implicated in pistillate floral production (Wood, 1989; Worley, 1979a) or decreasing certain phytohormones or growth regulators involved in level-two long-distance floral signaling (Bangerth, 2009; Wood, 2011).

Typically current-season's reproductive shoots end in a pistillate flower cluster. Occasionally, lateral buds initiate growth; thus, the distal portion of a reproductive shoot is vegetative. Next year's pistillate flowers develop from lateral buds (bearing shoots) or terminal and lateral buds (vegetative shoots) on one-year-old branches. These buds produce current-season shoots that end in pistillate

Received for publication 11 Dec. 2012. Accepted for publication 10 Jan. 2013.

Funded by the Oklahoma Agricultural Experiment Station and Oklahoma Pecan Growers' Association. ${ }^{1}$ Regents Professor.

${ }^{2}$ Research Technician.

${ }^{3}$ To whom reprint requests should be addressed; e-mailmike.smith@okstate.edu. light interception (Hinrichs, 1961; Lombardini, 2006), mineral nutrition (Smith et al., 2012), groundcover vegetation (Smith, 2011), water (drainage, conservation, and irrigation) (Kallestad et al., 2006; Smith and Bourne, 1989), pest control (Mulder et al., 2011), and crop load (Reid et al., 1993; Smith and Gallott, 1990; Smith et al., 1993). Certain arthropod pests and disease occasionally cause partial defoliation on individual shoots [for example, Hyphantria cunea (Drury), Datana integerrima Grote and Robinson, Melanocallis caryaefoliae (Davis), Cladosporium caryigenum (Ellis and Langl.) Gottwald]. The degree of defoliation varies from a few leaflets on a compound leaf to entire shoots defoliated. This localized defoliation may affect subsequent pistillate flower production.

The objective of this study was to evaluate the effect of localized defoliation (shoot level) on return bloom. Specifically, the location and amount of defoliation on a shoot and defoliation time were investigated to determine the effect of subsequent flowering on the same shoot.

\section{Materials and Methods}

flowers or remain vegetative. Pistillate flower induction takes place in early August (Amling and Amling, 1983), but differentiation is delayed until bud swell in March (Wetzstein and Sparks, 1983). Vernalization has been suggested as a requirement for floret formation (differentiation) in pecan (Amling and Amling, 1983). In Arabidopsis, a fundamental mechanism of the photoperiodic and autonomous pathways was delivery of sugar to the shoot apex (van Nocker, 2001). Vernalization and autonomous pathways converge on the negative regulation of flowering locus $\mathrm{C}$ (Ausín et al., 2004). In pecan, vernalization may enhance sugar transport to induced meristems, avoiding meristem reversion to the vegetative state and favoring pistillate flower differentiation. Cultivars receiving inadequate chilling may have greater reversion of induced meristems resulting in less production.

Unraveling environmental and cultural conditions that influence flowering is complex, but research combined with persistence has yielded positive results. Pistillate flower induction and eventual differentiation appears to be influenced both locally (shoot or branch) and at the whole tree level. For instance, fruit removal on an individual shoot positively impacts return bloom of the same shoot on certain cultivars (Smith et al., 1986). Shoots with fruit have a greater likelihood of flowering the next year than vegetative shoots if the cultivar has a moderate alternate bearing index, but the likelihood is less if the cultivar severely alternate bears (Rohla et al., 2007a). The tree's total cropload appears to have more impact on return bloom than the fruit load on an individual shoot, even if stored non-structural carbohydrates are abundant (Rohla et al., 2007b).

Several cultural practices have been developed that mitigate irregular bearing. These include management of the tree canopy for
Studies were conducted at the Cimarron Valley Research Station near Perkins, OK (lat. $35^{\circ} 59^{\prime} 35^{\prime \prime} \mathrm{N}$, long. $97^{\circ} 02^{\prime} 34^{\prime \prime} \mathrm{W}, 283 \mathrm{~m}$ elevation). Soil at the station is Teller sandy loam (fine-loamy, mixed, thermic, Udic Argiustoll). Trees were fertilized based on leaf analysis results (Smith et al., 2012) and pest control followed commercial guidelines (Mulder et al., 2011). Typically, nitrogen $(\mathrm{N})$ was applied during March using a tractor-pulled broadcast spreader at a rate of $112 \mathrm{~kg} \cdot \mathrm{ha}^{-1} \mathrm{~N}$ from urea. Three to five annual foliar applications of zinc sulfate $(36 \% \mathrm{Zn})$ at $6.5 \mathrm{~kg} \cdot \mathrm{ha}^{-1}$ were applied when the first leaf began to unfurl and then at 2to 3-week intervals. Other elements were ground-applied as a broadcast application if their concentration was below the leaf elemental sufficiency range.

Expt. 1. Trees used in the study were 'Maramec' on Apache seedling rootstock planted in Mar. 1981. Trees were initially spaced $12.2 \mathrm{~m} \times 12.2 \mathrm{~m}$, and then trees were thinned diagonally among rows in 2001 to $15 \mathrm{~m} \times 15 \mathrm{~m}$. Trees were irrigated with a buried dripline $2.5 \mathrm{~m}$ from the trunk on each side of the tree with emitters spaced at $0.6 \mathrm{~m}$. Irrigation application was based on the farm manager's judgment.

Treatments were shoot type, either vegetative or fruiting, and defoliation treatment. Defoliation treatments on individual shoots consisted of removal of all leaves, leaves on the basal one-half of the shoot, leaves on the distal one-half of the shoot, or not defoliated. Defoliation treatments were applied by hand in mid-September each year. Each treatment combination consisted of 20 shoots per tree replicated on five trees (two shoot types $\times$ four defoliation types; 160 total shoots/tree; 100 shoots/treatment). All vegetative and bearing shoots selected for the study were in the terminal position on one-year-old 
branches, 10 to $17 \mathrm{~cm}$ long, and bearing one to three fruit. The study was conducted in 2005 and 2008.

The next May, the position of the currentseason shoot on the one-year-old branch (terminal or lateral) was recorded and the number of flowers per current-season shoot was counted. Data were analyzed as a randomized complete block (tree served as block) with subsamples (individual shoots were subsamples) using a mixed model with the Kenwardroger option used to calculate the denominator df (Littell et al., 1996). Treatment means were compared using orthogonal contrasts and by comparisons within shoot type to the foliated control using the protected least significant difference at the 5\% level.

Expt. 2. Trees in this study were 'Maramec' on Colby seedling rootstock planted in Oct. 1993 and spaced $12.2 \mathrm{~m} \times 12.2 \mathrm{~m}$. Trees were not irrigated. Treatments were the same as in Expt. 1 and applied during midSept. 2009. Each treatment combination consisted of 10 shoots per tree replicated on 10 trees. Shoots selected for the study were 20 to $35 \mathrm{~cm}$ long with two to five fruit per shoot. Data collection and analysis were as described for Expt. 1.

Expt. 3. 'Kanza' grafted on Giles seedling rootstock irrigated with solid set sprinklers were used for this study. Trees were planted in Feb. 2000 at $7.6 \mathrm{~m} \times 10.7 \mathrm{~m}$ and were thinned in winter of 2009-10 to $10.7 \mathrm{~m} \times 15.2 \mathrm{~m}$.

Shoots that were 20 to $25 \mathrm{~cm}$ long bearing four to five fruit were selected for the study. Treatments were individual shoot defoliation as described previously and were applied 22 July, 22 to 23 Aug., or 22 Sept. 2010.
None of the defoliation treatments resulted in budbreak and shoot refoliation during the same growing season. Each treatment combination consisted of 10 shoots per tree (subsamples) on 10 trees (blocks). Data collection was as described in Expt. 1. Data were analyzed as a split plot with defoliation treatment serving as the main plot, defoliation date as the subplot, and shoots as the subsample using a mixed model analysis with the Kenwardroger option used to calculate the denominator df (Littell et al., 1996). Means were computed using the least squares technique and compared using single df orthogonal contrasts.

\section{Results}

The effect of treatment on the number of new shoots per one-year-old branch was minimal or inconsistent among years (Table 1). In 2006 , shoots that were vegetative with any defoliation produced an average of 0.2 more current-season shoots than those not defoliated. In 2009, vegetative shoots with basal defoliation produced slightly more shoots than those not defoliated, but other defoliation treatments were similar. Defoliation treatments did not affect shoot production on branches with fruit the previous year in 2006 and 2009, but in 2010, defoliation increased current-season shoot production. Currentseason shoot production was enhanced on previously vegetative compared with bearing branches in one of three years.

Defoliation had minimal effects on the number of pistillate flowers derived from one-year-old branches (Table 1). In 2006, branches with basal defoliation that were vegetative the previous year had more flowers than previously bearing branches. Otherwise, flower production was unaffected in 2006 or 2009. In 2010, defoliation enhanced flower production of previously bearing shoots. In addition, previously bearing branches produced more flowers than those that were vegetative if defoliation was distal or total.

Percentage of shoots with pistillate flowers on all current-season shoots or only those in the terminal position on a one-year-old branch were analyzed (Table 2). The main effect of the previous year's fruit bearing status did not affect fruiting of current-season shoots throughout the study. In 2006, defoliation suppressed current-season fruiting if branches were previously vegetative, but not if they were fruit-bearing. Terminal shoots producing fruit were dramatically inhibited by defoliation $(80 \%$ fruiting when foliated vs. $67 \%$ fruiting with partial or total defoliation) in 2006. Fruit production in 2009 was low compared with other years and was compromised by a late spring frost that damaged some developing shoots. No treatment affected current-season shoot flowering in 2009. Data in 2010 were similar to that in 2006. Fruiting of all shoots developing from previously vegetative branches was reduced by defoliation, but if the branch had fruit previously, defoliation had no effect on current-season fruiting shoots. Defoliation restrained current-season terminal shoots bearing fruit $(90 \%$ fruit bearing when foliated vs. $82 \%$ fruit bearing with partial or total defoliation). Previous year's branch bearing status did not affect current-year bearing shoot percentage.

Table 1. The influence of shoot type [vegetative (V) versus fruiting (F)] and shoot defoliation treatment on the number of new shoots and pistillate flowers developing per one-year-old branch on 'Maramec' pecan. ${ }^{2}$

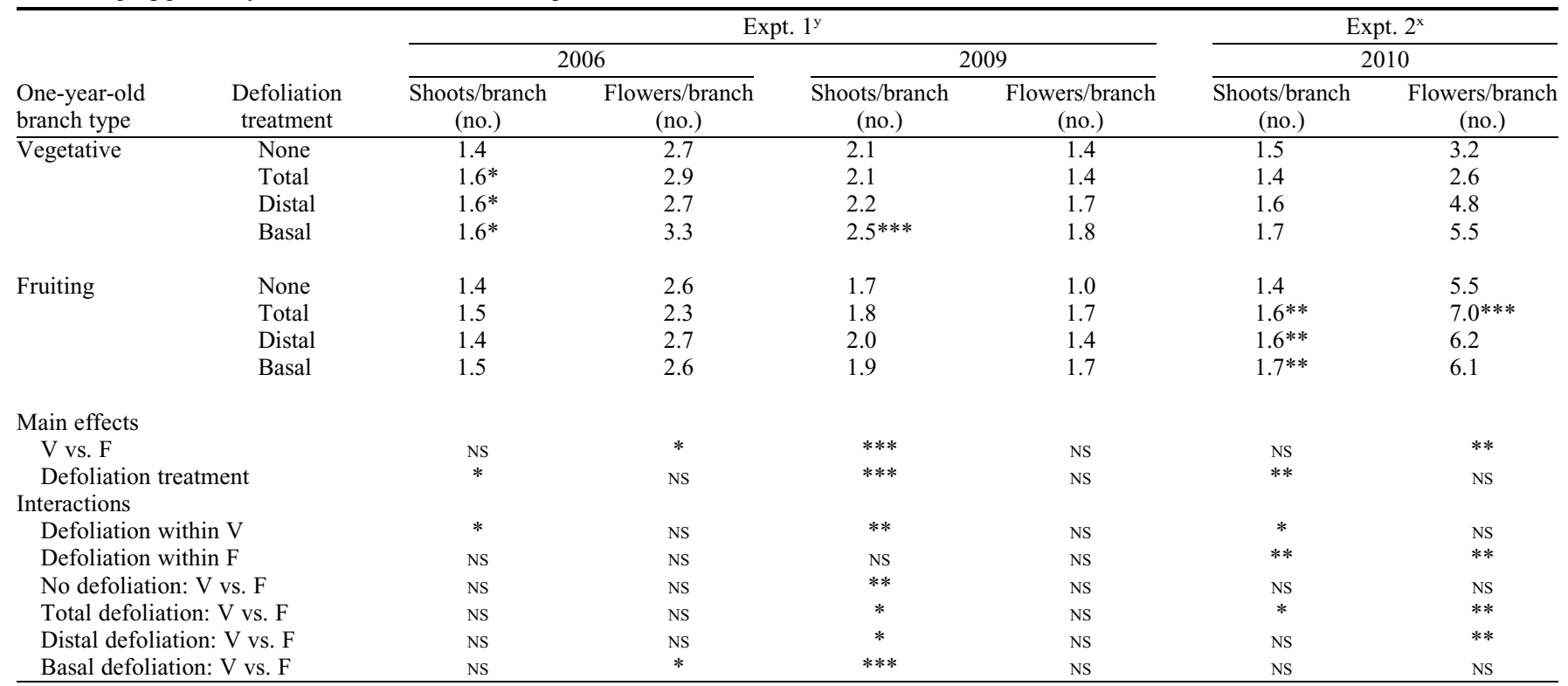

${ }^{2}$ Defoliation treatments were none, total shoot defoliated, distal one-half defoliated. and basal one-half defoliated. Defoliation treatments were applied by hand in mid-September and results measured the next May. Spring frost in 2009 damaged emerging shoots.

'Trees planted Mar. 1981.

${ }^{\mathrm{x}}$ Trees planted Oct. 1993 .

Ns, ${ }^{*}, * * * * *$ Nonsignificant, or significant at $* 5 \%, * * 1 \%$, or $* * * 0.1 \%$. Means followed by asterisk(s) are significantly different from the control (none) within the same shoot type (vegetative or fruiting) by the protected least significant difference. 
Table 2. The influence of shoot type [vegetative (V) versus fruiting (F)] and shoot defoliation treatment on the percentage of current season shoots flowering (terminal and lateral shoots) and terminal current-season shoots flowering on 'Maramec' pecan. ${ }^{\mathrm{z}}$

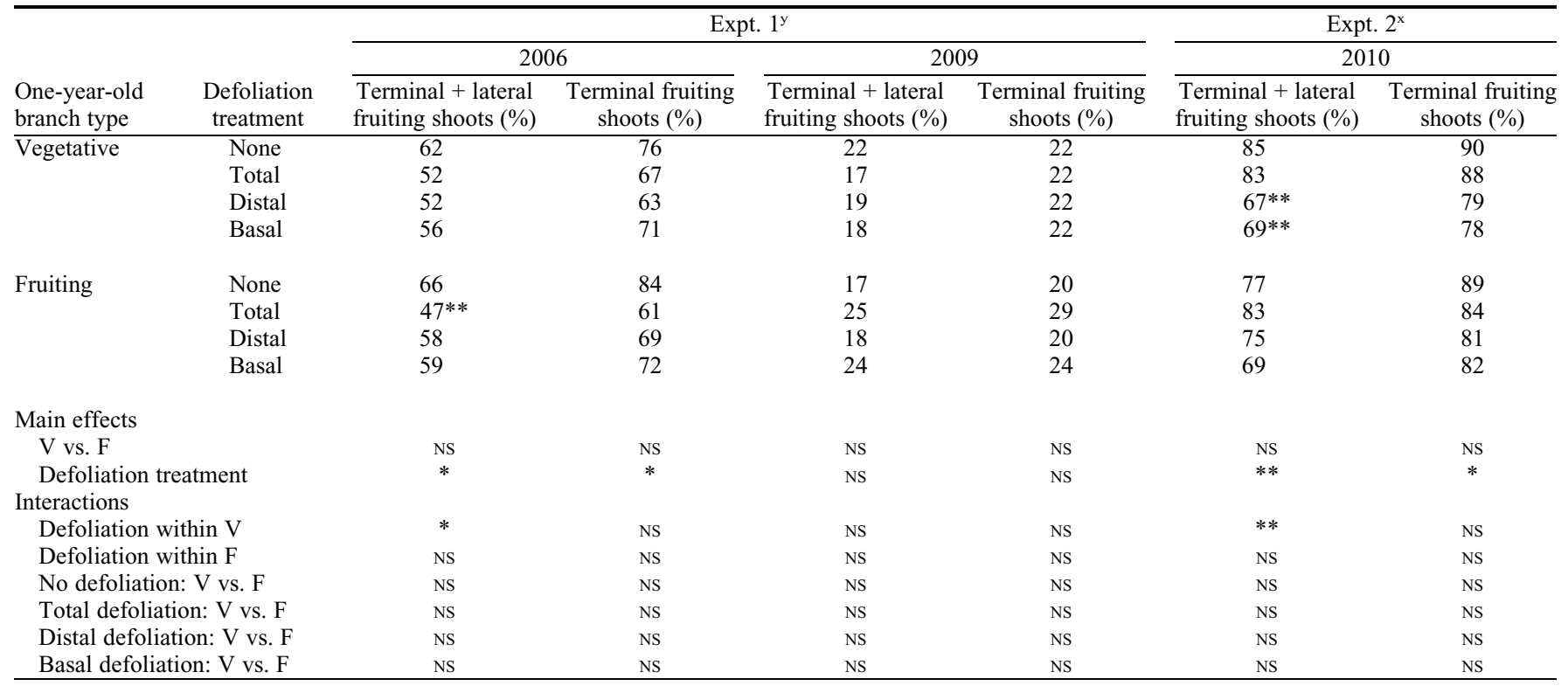

${ }^{\mathrm{z}}$ Defoliation treatments were none, total shoot defoliated, distal one-half defoliated, and basal one-half defoliated. Defoliation treatments were applied by hand in mid-September and results measured the next May. Spring frost in 2009 damaged emerging shoots.

${ }^{\mathrm{y}}$ Trees planted Mar. 1981.

xTrees planted Oct. 1993.

Ns, $*, * *, * *$ Nonsignificant or significant at $* 5 \%, * * 1 \%$, or $* * * 0.1 \%$. Means followed by asterisk(s) are significantly different from the control (none) within the same shoot type (vegetative or fruiting) by the protected least significant difference.

Neither defoliation treatment nor date the treatment was applied affected the number of current-season shoots per branch, percentage of current-season shoots fruiting, or currentseason shoots in the terminal position fruiting on 'Kanza' trees (Table 3). The number of flowers arising from a one-year-old fruiting branch was slightly greater if the basal portion of the shoot was defoliated in September rather than in July or August. Otherwise, defoliation treatment and defoliation time did not affect the number of flowers produced from one-year-old branches.

\section{Discussion and Conclusions}

Data from this study indicated that maintaining healthy leaves on an individual shoot was not essential for subsequent pistillate flower production but sometimes moderately increased pistillate flowers of 'Maramec' (Table 1). Defoliation times ranging from late July to late September had virtually no effect on return bloom of 'Kanza' (Table 3). Others (Hinrichs, 1962; Worley, 1979a) reported defoliating one-half to the entire canopy in early August or September virtually eliminated return bloom with the negative effects of premature defoliation decreasing by early October. The contrast between those studies and the present study was individual shoot defoliation vs. a large portion or the entire canopy. Another difference was August and September defoliation resulted in refoliation in those studies where large portions or the entire canopy was defoliated, whereas individual shoot defoliation that represented a small portion of the canopy did not cause refoliation. When Hinrichs (1962) defoliated
Table 3. Expt. 3: The influence time of defoliation and shoot defoliation treatment on the number of new shoots and flowers produced per one-year-old branch. ${ }^{\mathrm{z}}$

\begin{tabular}{|c|c|c|c|c|c|}
\hline $\begin{array}{l}\text { Month treatment } \\
\text { applied }\end{array}$ & $\begin{array}{l}\text { Defoliation } \\
\text { treatment }\end{array}$ & $\begin{array}{l}\text { Shoots/branch } \\
\text { (no.) }\end{array}$ & $\begin{array}{l}\text { Flowers/branch } \\
\text { (no.) }\end{array}$ & $\begin{array}{l}\text { Terminal }+ \text { lateral } \\
\text { fruiting shoots }(\%)\end{array}$ & $\begin{array}{c}\text { Terminal } \\
\text { fruiting } \\
\text { shoots }(\%)\end{array}$ \\
\hline \multirow[t]{4}{*}{ July } & None & 1.8 & 1.2 & 24 & 29 \\
\hline & Total & 1.6 & 0.8 & 31 & 26 \\
\hline & Distal & 1.7 & 1.0 & 24 & 41 \\
\hline & Basal & 1.7 & 1.3 & 30 & 49 \\
\hline \multirow[t]{4}{*}{ August } & None & 1.8 & 1.3 & 26 & 29 \\
\hline & Total & 1.6 & 0.7 & 16 & 24 \\
\hline & Distal & 1.7 & 0.9 & 18 & 17 \\
\hline & Basal & 1.7 & 1.0 & 23 & 38 \\
\hline \multirow[t]{4}{*}{ September } & None & 1.6 & 0.8 & 17 & 30 \\
\hline & Total & 1.7 & 0.9 & 20 & 27 \\
\hline & Distal & 1.7 & 1.2 & 20 & 37 \\
\hline & Basal & 1.9 & 0.8 & 20 & 33 \\
\hline \multicolumn{6}{|l|}{ Date main effects } \\
\hline \multicolumn{2}{|c|}{ July + August vs. September } & NS & NS & NS & NS \\
\hline \multicolumn{2}{|c|}{ July vs. August } & NS & NS & NS & NS \\
\hline \multicolumn{6}{|c|}{ Defoliation main effects } \\
\hline \multicolumn{2}{|c|}{ None vs. any defoliation } & NS & NS & NS & NS \\
\hline \multicolumn{2}{|c|}{ Total vs. partial defoliation } & NS & NS & NS & NS \\
\hline \multicolumn{2}{|c|}{ Distal vs. basal defoliation } & NS & NS & NS & NS \\
\hline \multicolumn{6}{|l|}{ Interactions } \\
\hline \multicolumn{2}{|c|}{$\begin{array}{l}\text { (July }+ \text { August vs. September) } \\
\text { (none vs. any defoliation) }\end{array}$} & NS & NS & NS & NS \\
\hline \multicolumn{2}{|c|}{$\begin{array}{r}\text { (July }+ \text { August vs. September) } \\
\text { (total vs. partial defoliation) }\end{array}$} & NS & NS & NS & NS \\
\hline \multicolumn{2}{|c|}{$\begin{array}{r}\text { (July }+ \text { August vs. September) } \\
\text { (distal vs. basal defoliation) }\end{array}$} & NS & $*$ & NS & NS \\
\hline \multicolumn{2}{|c|}{$\begin{array}{l}\text { (July vs. August)(none vs. any } \\
\text { defoliation) }\end{array}$} & NS & NS & NS & NS \\
\hline \multicolumn{2}{|c|}{$\begin{array}{l}\text { (July vs. August)(total vs. partial } \\
\text { defoliation) }\end{array}$} & NS & NS & NS & NS \\
\hline \multicolumn{2}{|c|}{$\begin{array}{l}\text { (July vs. August)(distal vs. basal } \\
\text { defoliation) }\end{array}$} & NS & NS & NS & NS \\
\hline
\end{tabular}


one-half of the tree, the two parts of the canopy responded differently; return bloom was suppressed by defoliation. Hand defruiting one-half of a pecan tree resulted in a greater return bloom on the defruited side compared with retaining fruit (Reid et al., 1993). Sparks and Brack (1972) hand-defoliated or defruited limbs that were $10 \mathrm{~cm}$ or larger at their base. Defruiting increased return bloom and defoliation suppressed return bloom. Studies clearly support whole tree leaf retention as a major contributing factor in return bloom (Hinrichs, 1962; Worley, 1979a), but differential responses within the canopy are possible if the unit is sufficiently large (Hinrichs, 1962; Reid et al., 1993; Sparks and Brack, 1972). Apparently, there is enough interaction allowing a small portion of the canopy such as an individual shoot to defoliate with the negative effects mitigated by the positive influence from the rest of the tree. Rohla et al. (2007a) concluded that the whole tree cropload was more important than the fruit load on an individual shoot in determining if that shoot would produce pistillate flowers the next year. These data support his conclusion in that the primary influence on subsequent pistillate flower production is based on the entire tree and secondarily and to a far lesser extent on fruit or leaf load on individual shoots.

The implication of this conclusion influences assessment of crop overload and the need for mechanical fruit thinning (Smith and Gallott, 1990). Vigorous trees frequently appear overloaded on the lower two-thirds of the canopy, but the top one-third has minimal fruit and substantial foliage. Similarly, hedge-pruned trees have areas in the canopy where fruit is abundant and other locations with few fruit but abundant foliage. Initial recommendations were to judge the cropload at the middle of the canopy rather than considering the cropload throughout the canopy. It was further assumed that individual shoots tended to act autonomously with larger fruit clusters decreasing both nut quality and return bloom. However, cluster size had a minimal effect on nut quality and return bloom (Rohla et al., 2007b), and individual shoot defoliation demonstrated a strong interaction with unaffected areas mitigating negative effects of defoliation (Tables 1 to 3 ). Conclusions based on this body of evidence are that the entire tree cropload must be considered when determining crop overload and cluster size need not be considered under normal circumstances when making this judgment. The same body of data indicates that uneven fruit removal among canopy locations and within fruit clusters during mechanical fruit thinning (Smith et al., 1993) will have little impact on nut quality or return bloom.

\section{Literature Cited}

Amling, H.J. and K.A. Amling. 1983. Physiological differentiation of pistillate flowers of pecan and cold requirements for their initiation. J. Amer. Soc. Hort. Sci. 108:195-198.

Ausín, I., C. Alonso-Blanco, J.A. Jarillo, L. RuizGarcia, and J. Martínez-Zapater. 2004. Regulation of flowering time FVE, a retinoblastomaassociated protein. Nat. Genet. 36:162-166.

Bangerth, K.F. 2009. Floral induction in mature, perennial angiosperm fruit trees: Similarities and discrepancies with annual/biennial plants and the involvement of plant hormones. Sci. Hort. 122:153-163.

Hinrichs, H.A. 1961. The relationship of native pecan tree spacing to yield. Okla. Agric. Expt. Sta. Bul. B-574.

Hinrichs, H.A. 1962. Pecan industry and some research developments in Oklahoma. Northern Nut Growers' Assn. 58:80-85.

Kallestad, J.C., J. White, J.G. Mexal, and T.W. Sammis. 2006. Monitoring and management of pecan orchard irrigation: A case study. HortTechnology 16:667-673.

Kouzarides, T. 2007. Chromatin modifications and their function. Cell 128:693-705.

Littell, R.C., G.A. Milliken, W.W. Stroup, and R.D. Wolfinger. 1996. SAS system for mixed models. SAS Institute, Cary, NC.

Lombardini, L. 2006. One-time pruning of pecan trees induces limited and short-term benefits in canopy light penetration, yield, and nut quality. HortScience 41:1469-1473.

Mulder, P., E. Stafne, and D. Smith. 2011. Commercial pecan insect and disease control-2011. Okla. Coop. Ext. Curr. Rep. CR-6209.

Nelissen, H., T.M. Boccardi, K. Himanen, and M. Van Lijsebettens. 2007. Impact of core histone modifications on transcriptional regulation and plant growth. Crit. Rev. Plant Sci. 26:243263.

Reid, W., S.M. Huslig, M.W. Smith, N.O. Maness, and J.L. Whitworth. 1993. Fruit-removal time influences return bloom in pecan. HortScience 28:800-802.

Rohla, C.T., M.W. Smith, N.O. Maness, and W. Reid. 2007a. A comparison of return bloom and nonstructural carbohydrates, nitrogen and potassium concentrations in moderate and severe alternate-bearing pecan cultivars. J. Amer. Soc. Hort. Sci. 132:172-177.

Rohla, C.T., M.W. Smith, and N.O. Maness. 2007b. Influence of cluster thinning on return bloom, nut quality, and concentrations of potassium, nitrogen, and non-structural carbohydrates. J. Amer. Soc. Hort. Sci. 132:158-165.

Smith, M.W. 2011. Pecan production increased by larger vegetation-free area surrounding the tree. Sci. Hort. 130:211-213.

Smith, M.W. and R. Bourne. 1989. Effects of flooding pecan seedlings during dormancy, budbreak, and active growth. HortScience 24:81-83.

Smith, M.W. and J.C. Gallott. 1990. Mechanical thinning of pecan fruit. HortScience 25:414 416.

Smith, M.W., R.W. McNew, P.L. Ager, and B.C. Cotten. 1986. Seasonal changes in the carbohydrate concentration in pecan shoots and their relationship to flowering. J. Amer. Soc. Hort. Sci. 111:558-561

Smith, M.W., W. Reid, B. Carroll, and B. Cheary. 1993. Mechanical fruit thinning influences fruit quality, yield, return fruit set, and cold injury of pecan. HortScience 28:1081-1084.

Smith, M.W., C.T. Rohla, and W.D. Goff. 2012 Pecan leaf elemental sufficiency ranges and fertilizer recommendations. HortTechnology 22:594-599.

Smith, M.W. and P. Weckler. 2011. Industry meets to pinpoint research, extension priorities. Pecan South 44:14-18.

Sparks, D. and C.E. Brack. 1972. Return bloom and fruit set of pecan from leaf and fruit removal. HortScience 7:131-132.

van Nocker, S. 2001. The molecular biology of flowering. In: Janick, J. (ed.). Hort. Rev. 27: $1-39$.

Wetzstein, H.Y. and D. Sparks. 1983. The morphology of pistillate flower differentiation in pecan. J. Amer. Soc. Hort. Sci. 108:9971003.

Wood, B.W. 1989. Pecan production responds to root carbohydrates and rootstock. J. Amer. Soc. Hort. Sci. 114:223-228.

Wood, B.W. 2011. Influence of plant bioregulators on pecan flowering and implications for regulation of pistillate flower initiation. HortScience 46:870-877.

Worley, R.E. 1979a. Pecan yield, quality, nutlet set, and spring growth as a response of time of fall defoliation. J. Amer. Soc. Hort. Sci. 104:192-194.

Worley, R.E. 1979b. Fall defoliation date and seasonal carbohydrate concentrations of pecan wood tissue. J. Amer. Soc. Hort. Sci. 104:195199.

Yang, Y., J. Klejnot, X. Yu, X. Liu, and C. Lin. 2007. Florigen (II): It's a mobile protein. J. Integr. Plant Biol. 49:1665-1669. 